\title{
Building a common description of land cover in a tropical watershed plagued with intercultural conflicts: The value of participatory 3D modelling
}

\author{
Mathieu Guillemette $^{\mathrm{a} \star}$, Catherine Potvin ${ }^{\text {ab }}$, Lauliano Martinez ${ }^{\text {ac }}$, Bonarge Pacheco $^{\text {ad }}$, Dioniz Caño ${ }^{\text {ae }}$, \\ and Ignacio Pérez ${ }^{\text {af }}$ \\ ${ }^{a}$ Department of Biology, University McGill, Montreal, QC H3A 1B1, Canada; ${ }^{b}$ Smithsonian Tropical \\ Research Institute, Av. Roosevelt 401, Panamá, Balboa, Ancón 0843-03092, Republic of Panamá; \\ 'Organizacion Kuna de Madungandi, Av. Roosevelt 401, Panamá, Balboa, Ancón, Republic of Panamá; \\ ${ }^{\mathrm{d} C}$ Congreso General de Tierras Colletivas Embera y Wounaan, Av. Roosevelt 401, Panamá, Balboa, Ancón, \\ Republic of Panamá; 'Asociación de Productores Agropecuarios de Platanilla, Platanilla, Av. Roosevelt 401, \\ Panamá, Balboa, Ancón, Republic of Panamá; ${ }^{\mathrm{f}}$ Asociación Union de Campesinos de la Provincia de \\ Panama, Av. Roosevelt 401, Panamá, Balboa, Ancón, Republic of Panamá \\ *mathieu.guillemette@umontreal.ca
}

\section{OPEN ACCESS}

Citation: Guillemette M, Potvin C, Martinez L, Pacheco B, Caño D, and Pérez I. 20 17. Building a common description of land cover in a tropical watershed plagued with intercultural conflicts: The value of participatory 3D modelling. FACETS 2: 195-2 I I. doi: | 0.1 I39/facets-2016-0010

Editor: Raid Al-Tahir

Received: March 18, 2016

Accepted: December 20, 2016

Published: February 28, 2017

Copyright: (c) 2017 Guillemette et al. This work is licensed under a Creative Commons Attribution 4.0 International License (CC BY 4.0), which permits unrestricted use, distribution, and reproduction in any medium, provided the original author(s) and source are credited

Published by: Canadian Science Publishing

\section{Abstract}

Natural forest management and conservation projects such as reducing emissions from deforestation and forest degradation, and enhancing forest carbon stocks (REDD+) face many challenges in the field. Implementation of these projects depends on such factors as clarity of information among stakeholders, legal security of territories, and local decision-making power. These challenges have been previously identified in the Upper Bayano watershed of eastern Panama, where a long history of land cover and land-use conflicts is present between three different human groups. With a long-term objective of natural forest conservation, this study aims to develop and test participatory approaches (participatory mapping and participatory 3D modelling) for the Upper Bayano watershed in an attempt to create a consensus among all stakeholders on current land cover and land-use conflicts to overcome challenges faced by projects as REDD+. We found that the third dimension allows a common understanding over the landscape, creates a common ground discussion, and leads towards a consensus, while the participatory approach brings discussion and positive effects among the stakeholders and the bridging institutions bring equity and transparency. Finally, we discuss implications of this knowledge generation and common agreement over the landscape for future forest management projects such as REDD+'s implementation.

Key words: land use, REDD+, consensus, forest management, participatory mapping, participatory 3D modelling

\section{Introduction}

During the last decade (2004-2013), atmospheric $\mathrm{CO}_{2}$ emissions from fossil fuel and cement production represented $91 \%$ of the total, whereas emissions from land-use change represented 9\% (Le Quéré et al. 2015), most of which is attributable to deforestation in the tropics (Houghton et al. 2012). During the 2015 United Nations conference on climate change in Paris, parties recognized an increase 
in anthropogenic $\mathrm{CO}_{2}$ emissions and global climate change as an urgent treat to human societies and agreed to joint efforts over $\mathrm{CO}_{2}$ emission mitigation (United Nations 2015). As part of this international effort to limit global warming, reducing emissions from deforestation and forest degradation, and enhancing forest carbon stocks in developing countries (REDD+) initiative is an attempt to provide large-scale payments for developing countries to reduce emissions and increase forest carbon stock (Angelsen et al. 2009). To date, 47 developing countries (18 from Africa, 18 from Latin America, and 11 from the Asia-Pacific region) are taking part in a major effort to act on deforestation in the context of the World Bank's Forest Carbon Partnership Facility (2015). Successful REDD+ initiatives would mitigate global $\mathrm{CO}_{2}$ emissions caused by land-use changes and would enhance the important carbon sink that represents tropical forests (Foody et al. 1996).

In the field, REDD+ faces numerous challenges as its implementation depends on many factors such as information clarity among stakeholders, legal security of territories, and local power to make decisions (Sunderline et al. 2009; Galudra et al. 2011). This study is part of a long-term action research program of the Neotropical Ecology Laboratory at McGill University and the Smithsonian Tropical Research Institute focusing on REDD+ implementation in the Upper Bayano watershed in eastern Panama (Fig. 1) (St-Laurent et al. 2013; Holmes and Potvin 2014; Vergara-Asenjo and Potvin 2014). We chose to work in the Upper Bayano watershed because the Ascanio Villalaz hydroelectric dam located at the heart of the watershed provides electricity for Panama City. This dam, also known as the Bayano Dam, produced $160 \mathrm{MW}$ in 2013, and at the time was the third most important dam in the country (ETESA 2013). The Upper Bayano watershed is still largely forested; the long-term protection of its forests would therefore contribute to both REDD+ and water conservation.

The watershed is inhabited by three human groups: the Guna and Embera indigenous peoples and the campesinos (colonist farmers of Latino origin). In the 1970s, construction of the Ascanio Villalaz hydroelectric dam led to extension of the Pan-American Highway and also caused human resettlements (Wali 1989). Since then, the region has undergone constant colonization by campesinos (St-Laurent et al. 2013). Land invasion and forest clearing by campesinos on indigenous land have caused social conflicts and resulted in loss of large tracts of forests (Wali 1989; Sloan 2008). Members of our research group estimated that for the period 2001-2014 almost 30\% of forest losses in indigenous territories were due to land invasion (Vergara-Asenjo et al., Submitted). In recent years, land conflicts among the three sectors were acute, resulting in several murders (Berger 2013; Rodriguez 2014b).

With the perception of increased drought and water shortage (Sloan 2008) and a deforestation rate rising at $11 \%$ per year in some indigenous areas, focusing almost exclusively on primary forest (Autoridad Nacional del Ambiente 2014), Guna and Embera indigenous authorities and campesino representatives have all recognized that historical and current patterns of land use may compromise future human population well-being, both locally in the Upper Bayano and nationally. In 2011, all three sectors expressed interest in finding a solution to the long-standing land cover and land-use conflicts and together developed the project Juntos para proteger nuestra Cuenca. The long-term goal of this project, which started in 2013, is to conserve and restore the highly threatened tropical forest ecosystems of eastern Panama by empowering the local population. The project was developed in partnership with the Gunas' General Congress (Organización Kuna de Madungandi, ORKUM), the Emberas' General Congress, the Asociación de Productores Agropecuarios de Platanilla (APAP), the Asociación Union de Campesinos de la Provincia de Panama (AUCPP), the NGO Dobo Yala Foundation, with the Neotropical Ecology Laboratory at McGill University and the Smithsonian Tropical Research Institute as bridging institutions. Since its implementation, the project has fulfilled many of its objectives: (1) producing a proposal for a conflict resolution mechanism based on mediation rather than government intervention; (2) presenting workshops to local farmers on sustainable agriculture; (3) training local technicians on carbon inventory methods and uses and measuring forest carbon of the Comarca 


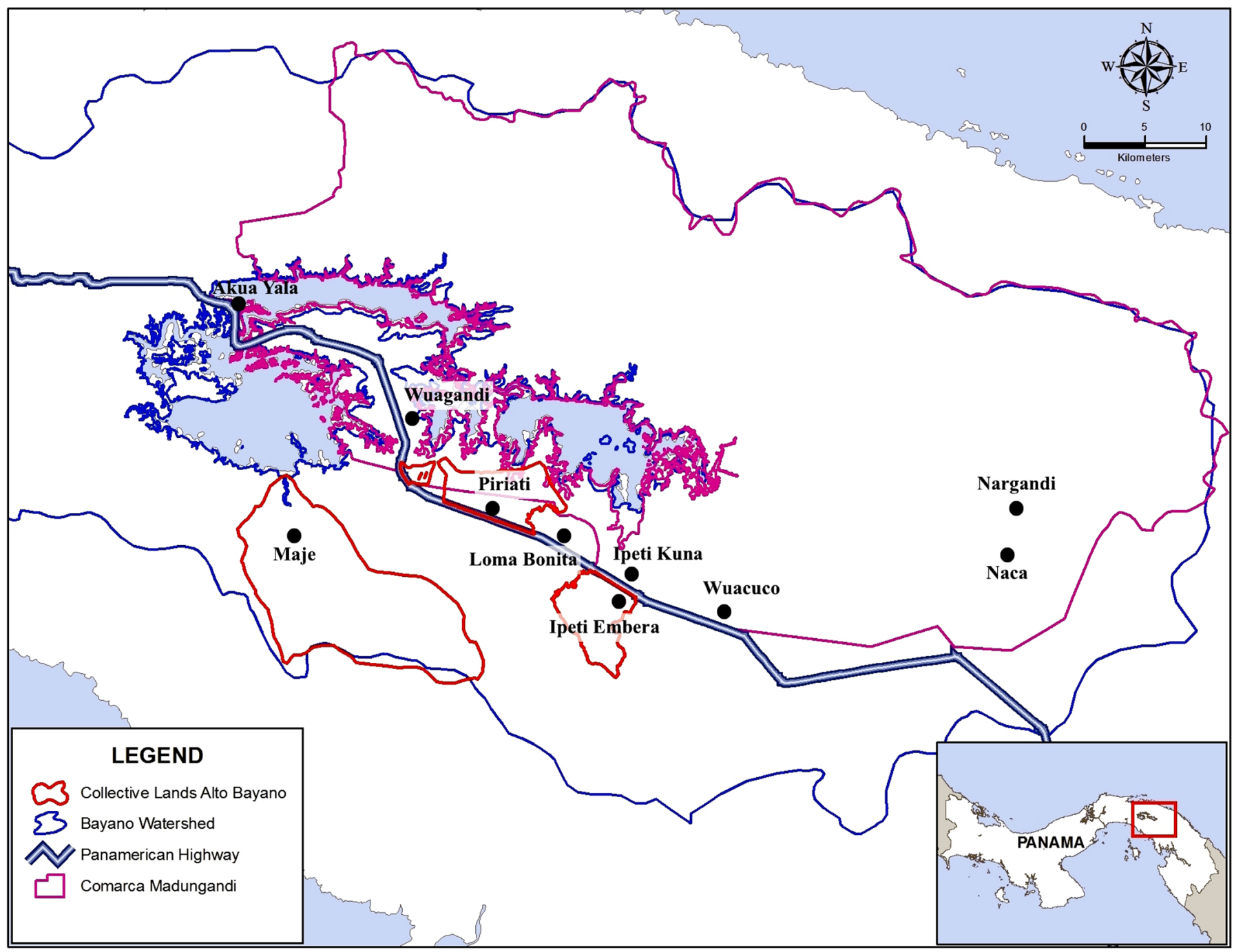

Fig. 1. The area plotted on the 3D model covering the Upper Bayano region. The map shows indigenous land and watershed delimitation as participatory mapped or conflicted villages. Attribution: Milton Solano (Smithsonian Tropical Research Institute).

Kuna de Madugandi; and (4) building functional relationships among youths through video training and production, film festivals, and intercultural exchange. The innovative approaches to advancing forest conservation in the Bayano have been recognized with first prize at the 2016 Yale International Society of Tropical Foresters 22nd International Society of Tropical Foresters (ISFT) Conference.

Building on the productive dialogue around land use that emerged in the Upper Bayano (Amado et al. 2014), this study used participatory approaches to build a consensus around current land cover and land-use conflicts. We defined "consensus" as a meeting of the minds by all parties sufficient to make decisions and carry them out (Arthur et al. 1999). This baseline representation of land cover should enable the understanding of past and present land cover and land-use changes, thus helping to design future land-use scenarios (Sloan 2008). The study's salient feature is its intercultural focus with the interactive participation of three different sectors and a common desire to break down strong barriers that exist among them. Rather than considering any of these human groups in isolation, this study 
sought to foster a dialogue among them to help develop a consensus around land cover and land use in the entire watershed.

Participatory research seeks to develop creative and adaptive information systems based primarily on the information needs of insiders (FAO 1990). Participatory mapping, for example, is frequently used, as local people hold rich and complex knowledge about their land compared with outsiders (Mialhe et al. 2015), which helps communities to make decisions on land use that fit local realities (NOOA 2009, 3; Mialhe et al. 2015). In situations where it is easy to imagine that less powerful stakeholders could be sidelined for the benefit of more powerful ones (Sunderline et al. 2009), participatory research has the ability to empower local, marginalized stakeholders (FAO 1990; NOOA 2009). This makes participatory mapping approaches relevant in remote locations like the Upper Bayano region.

In 1987, an extension of participatory mapping was developed by adding a vertical dimension to maps (Rambaldi et al. 2002). Participatory 3D modelling (P3DM) was developed to increase community participation in problem analysis and decision-making by the use of a more visual tool (Rambaldi and Lanh 2003). Since then, P3DM is being used worldwide in various projects (P3DM 2016). It has proven to be very useful in a wide range of land-use planning projects (Mascarenhas and Kumar 1991). For instance, it was used with success in multicultural watershed land-use planning and conflict resolution in northern Thailand (Tan-Kim-Yong 1992; Srimongkontip 2000), in landuse planning inside a national park in Vietnam (Rambaldi and Lanh 2003), and in risk disaster planning in remote islands of the Philippines (Gaillard and Maceda 2009; Maceda et al. 2009).

In this study, the objective of the P3DM exercise was to gather participants of the three sectors, including traditional indigenous authorities and influential campesinos, around the construction of a 3D model that would represent the current Upper Bayano landscape, including historical and existing land cover and land-use conflicts. As such, the objective was that the 3D model would illustrate a common definition of land cover and land-use conflicts. According to Amado et al. (2014), successful conflict resolution entails three key factors: (1) the definition of the conflict itself, (2) the resources available to move conflict resolution along, and (3) the structure of the decision-making group. We propose the P3DM of the Bayano watershed as a critical element of the problem definition agreed upon by the key stakeholders.

\section{Materials and methods}

\section{Study site}

This project took place in the Upper Bayano watershed in eastern Panama, a region covering a total area of $4844 \mathrm{~km}^{2}$ (Fig. 1), with the entire area covering $6252 \mathrm{~km}^{2}$. The watershed is bounded on the south by the Maje Cordillera and on the north by the San Blas Cordillera with the artificial Bayano Lake $\left(350 \mathrm{~km}^{2}\right)$ in the center (Wali 1989). The watershed is located in both the provinces of Panama and the Darien and includes indigenous territories: the Comarca Kuna de Madugandi (208 550 ha, created in 1996) and the collective lands of Ipeti Embera (3285 ha), Piriati Embera (3869 ha), and Maje (18 920 ha) created in 2014 and 2015, respectively (Panama 1996; Vergara-Asenjo et al. 2015). Maje is the only indigenous territory of the Upper Bayano that is not yet legally recognized.

In the 1970s, both indigenous groups were resettled after the construction of the Ascanio Villalaz dam and promised legal land titles for their new territories as well as financial compensation for the flooding of their ancestral territories (Wali 1989). Panama's government failure to grant land titles and give financial compensation led Gunas and Emberas to bring the government of Panama to the InterAmerican Court of Human Rights. The Court ruled a process that culminated in favor of the indigenous groups in 2014 (la Corte Interamericana 2014, 66) and the collective lands of Piriati and Ipeti were officially granted their collective land titles in 2014 and 2015, respectively. 


\section{Participatory mapping}

To understand current land use within each sector and to improve the $3 \mathrm{D}$ model resolution through the use of these participatory maps, participatory mapping sessions were carried out for each sector over a period of 2 years. The mapping of Embera communities was carried out in 2013 in the Tierras colectivas of Ipeti, Piriati, and Maje as described by Vergara-Asenjo et al. (2015) (Fig. 1). The mapping of campesinos was carried out around the community of Loma Bonita (Fig. 1), where 70 households were visited and participated in the mapping, representing a group of 44 males and 26 females ranging from 24 to 72 years of age (Potvin et al., In Preparation). A 5 m resolution multi-spectral Rapideye ${ }^{\circledR} 2012$ images map was used, and a plastic sheet (acetate) was placed over it to allow drawing over the satellite image.

Participatory mapping in the Comarca Kuna de Madugandi was carried out in July 2015 in a subset of 4 of 14 communities: Nargandi, Naca, Ipeti Kuna, and Wuagandi (Fig. 1). The four communities vary in population size, degree of remoteness from the highway, and traditional practices, and correspond to the three geographical sectors recognized internally by the Comarca: communities alongside the lake, rivers, and roads. Mapping built on the methodology used earlier for the Emberas' communities, relying on a base map with main rivers and roads and a $30 \mathrm{~m}$ resolution satellite imagery map from the Environmental Systems Research Institute (ESRI) 2012. For each community, the exercise took $2 \mathrm{~d}$.

Each exercise began with a meeting with the village authorities. During these meetings, one of the authors (LM) explained in the Guna language the mapping purpose and methodology. Once mapping received approval from the local authorities, they appointed a working group. (Note: at all steps of this project, we followed McGill's Protocols and Ethics in Aboriginal Environment in Panama, and staff members were certified by National Institute of Health of the United States of America.) Although we indicated our preference for a balanced ratio of gender and age, groups were mainly composed of adult men. Mapping started by listing the landscape features of the territory (e.g., trails, rivers, and streams) and agreeing on land cover categories. By midday, participants started drawing the trails, roads, rivers, and streams on a plastic sheet (acetate) affixed to the satellite imagery map. Then, using the acetate and carbon paper, they copied it onto the base map. These features served as references to locate land cover categories. Relying on these features, the participants were able to recall travelling their territory by following the landscape features and to draw each chosen land cover category. Land cover categories were chosen depending on the elements previously listed by participants. For example, no monoculture was present in communities; rather crops consisted of beans, cacao, coffee, plantain, rice, and yucca, so these were grouped as mixed agriculture. Land cover categories were as follows: primary forest, intervened forest, sacred forest, mixed agriculture, pasture, and cemeteries (Fig. 2). In total, 27 participants (five in Nargandi, seven in Naca, six in Ipeti Kuna, and nine in Wuagandi) created the four land cover maps.

\section{Participatory 3D modelling around the Upper Bayano watershed}

To map the landscape of the entire watershed, a P3DM approach was used, aiming to develop a consensus on land cover and land-use conflicts currently present in the region. The construction of the P3DM followed Rambaldi (2010) and consisted of three phases: preparatory, construction, and painting.

The preparatory phase lasted nearly 1 month. During this phase, participants were identified and materials were bought. Members of each sector selected a local coordinator to represent their sector throughout the process: LM representing the Gunas, BP representing the Emberas, and DC and IP representing campesinos. In turn, the local coordinators selected participants from their own sector. The work leading to the construction of the $3 \mathrm{D}$ model began with a workshop on $3 \mathrm{D}$ mapping, 

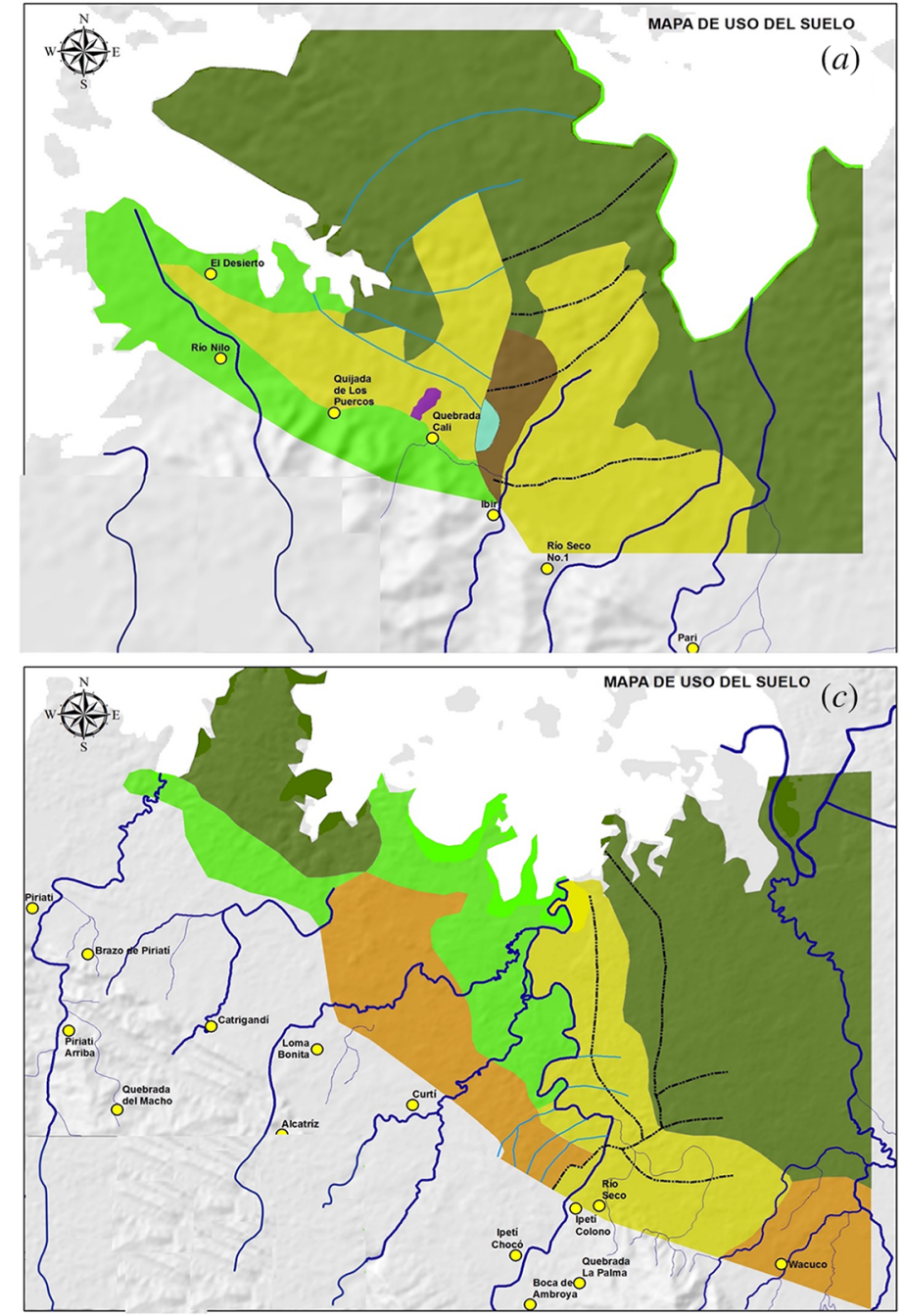

Fig. 2. Participatory maps of (a) Wuagandi, (b) Nargandi and Naca, and (c) Ipeti Guna.

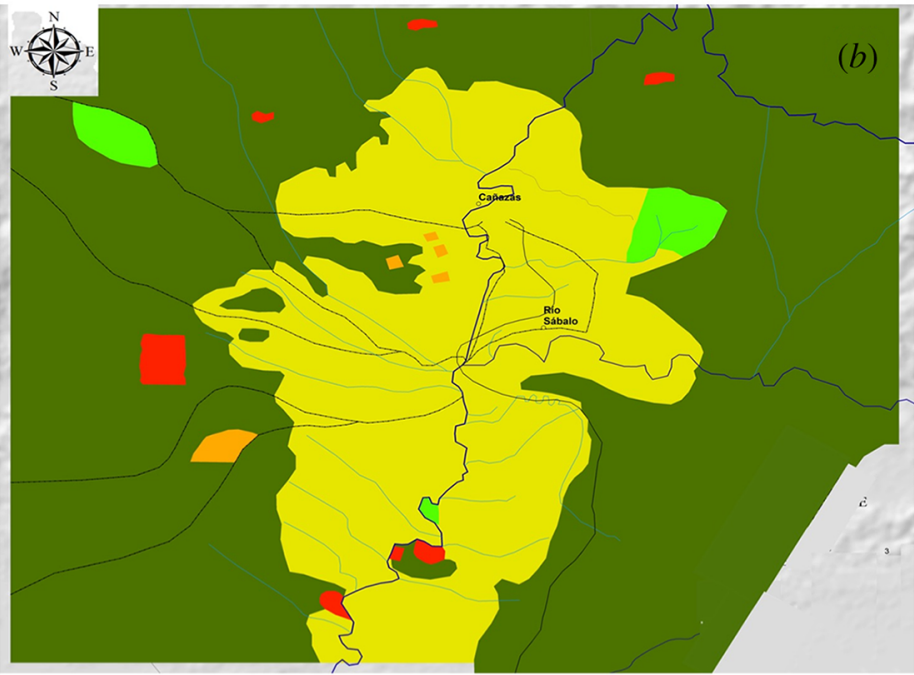

\section{Legend}
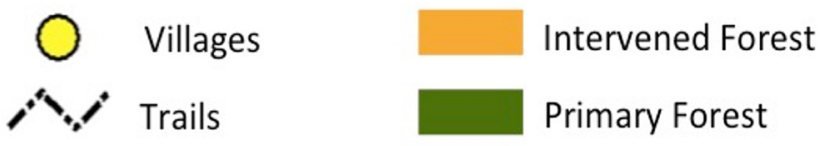

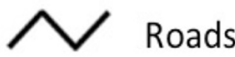

Pasture

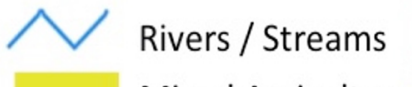

Village

Mixed Agriculture

Fallow

Rice Plantation

Sacred Forest

presenting photos and results of previous similar initiatives carried out by Rambaldi et al. (2002, 2007) in Vietnam and Kenya and by Tan-Kim-Yong (1992) in Thailand. The proposed methodology was discussed and adjusted to local circumstances based on participants' comments. Ten participants, selected by the local coordinators, attended the workshop (four Gunas, five Emberas, and one campesino). After the workshop, efforts were made to increase campesinos' participation.

Construction started with 12 participants (four Gunas, five Emberas, and three campesinos) but, as the exercise went on, people came and went depending on their availability. Additional participants joined as the process unfolded for a total of 39 participants. The first 12 were the core group who stayed for the majority of the modelling and painting phases. The other 27 were friends, relatives, authorities, or other inhabitants of the watershed. Most of them came for one or two sessions during the construction phase or only for the painting session of their sector.

The 3D model construction took $8 \mathrm{~d}$ separated into three sessions and resulted in a blank model of the Upper Bayano watershed with topography. We chose a scale of 1:45 000 because of the large area of 
the Upper Bayano watershed $\left(6256 \mathrm{~km}^{2}\right)$. The final 3D model is a rectangle of $1.52 \times 2.03 \mathrm{~m}$. A vertical exaggeration of 4.5 was implemented to increase the contrast of elevation and facilitate interpretation. The blank model was constructed using $5 \mathrm{~mm}$ thick laminated foamboard instead of cardboard to prevent it from degradation due to humidity. To reproduce the topography, we used an shuttle radar topography mission digital elevation model (SRTM DEM) $100 \mathrm{~m}$ interval contour line map from 2000 printed at the scale and size of the model, traditional white glue, carbon paper, gypsum paste, crepe paper, scissors, cutters, saw, nails, and a hammer. The construction crew was composed of six Emberas (two men and four women), six Gunas (six men and six women), and four campesinos (two men and two women).

The painting phase followed construction with the objective of reproducing the region's landscape features and land cover categories on the blank model. This took $4 \mathrm{~d}$ divided into four sessions. In the first session, the participants who built the model worked together to identify and paint fixed landscape features of their territory, e.g., rivers, lake, and roads. Features related to water were painted in different shades of blue, whereas roads were indicated with yarn. Those features were then used as references for the participants during land cover painting sessions. Once the landscape features were painted on the blank model, participants began to paint the limits of the three indigenous territories as well as land cover categories for the entire watershed. This phase was done one sector at a time, moving the model from one village to another. The Embera's painting was held in Ipeti Embera, the Guna's painting in Akua Yala, and the campesino's painting in Loma Bonita (Fig. 1). Information provided to participants for the painting phase included local participatory maps when available (see section above), a 2012 digitalized land cover categories map of the Panamanian Ministry of Environment (MiAmbiente), and an ESRI $201230 \mathrm{~m}$ resolution satellite images map.

The first sector to paint their land was the Emberas, using their three participatory maps. Second, the Gunas painted and delimited their Comarca using their four participatory maps, and the campesinos completed the unpainted area with their participatory map. When the participatory maps were not available, participants were asked if they knew what was on this land. If yes, they would paint it as they knew it, and if no, they would refer to the satellite map of ESRI and the digitalized map of MiAmbiente. Each sector chose its land cover categories, often following the land cover categories used in their participatory maps. The overall land cover categories retained for the 3D model were as follows: primary forest, intervened forest, sacred forest, pastures, agricultural land, plantations, and fallow. The end of this phase resulted in a complete 3D model of the Upper Bayano region (Fig. 3). In the indigenous territories, after each painting session, members of the local authorities came to see and approve the completed work. The participants involved in the painting were represented by eight Emberas (four men and four women), nine Gunas (four men and five women), and six campesinos (two men and four women).

\section{Locating land cover and land-use conflicts}

A final exercise located historical and present land cover and land-use conflicts on the 3D model. After painting the land cover categories, meetings were held one sector at a time with the traditional authorities (chiefs and delegates from Ipeti Embera and Piriati Embera communities and the Comarca Kuna de Madugandi) and "influential" locals, such as previous community delegates, or for the campesino side, members of local organizations. In total, participants consisted of five Emberas, three Gunas, and two campesinos (see Discussion section for more on campesinos' poor participation).

Prior to each session of conflict identification and mapping exercises, all participants were asked to look at conflicts identified by the other sectors and concur that the conflict exists. Additionally, they were asked to verify if any other conflicts were missing. The Emberas were the first sector to identify land cover and land-use conflicts; the information that they provided was verified by the Gunas and 


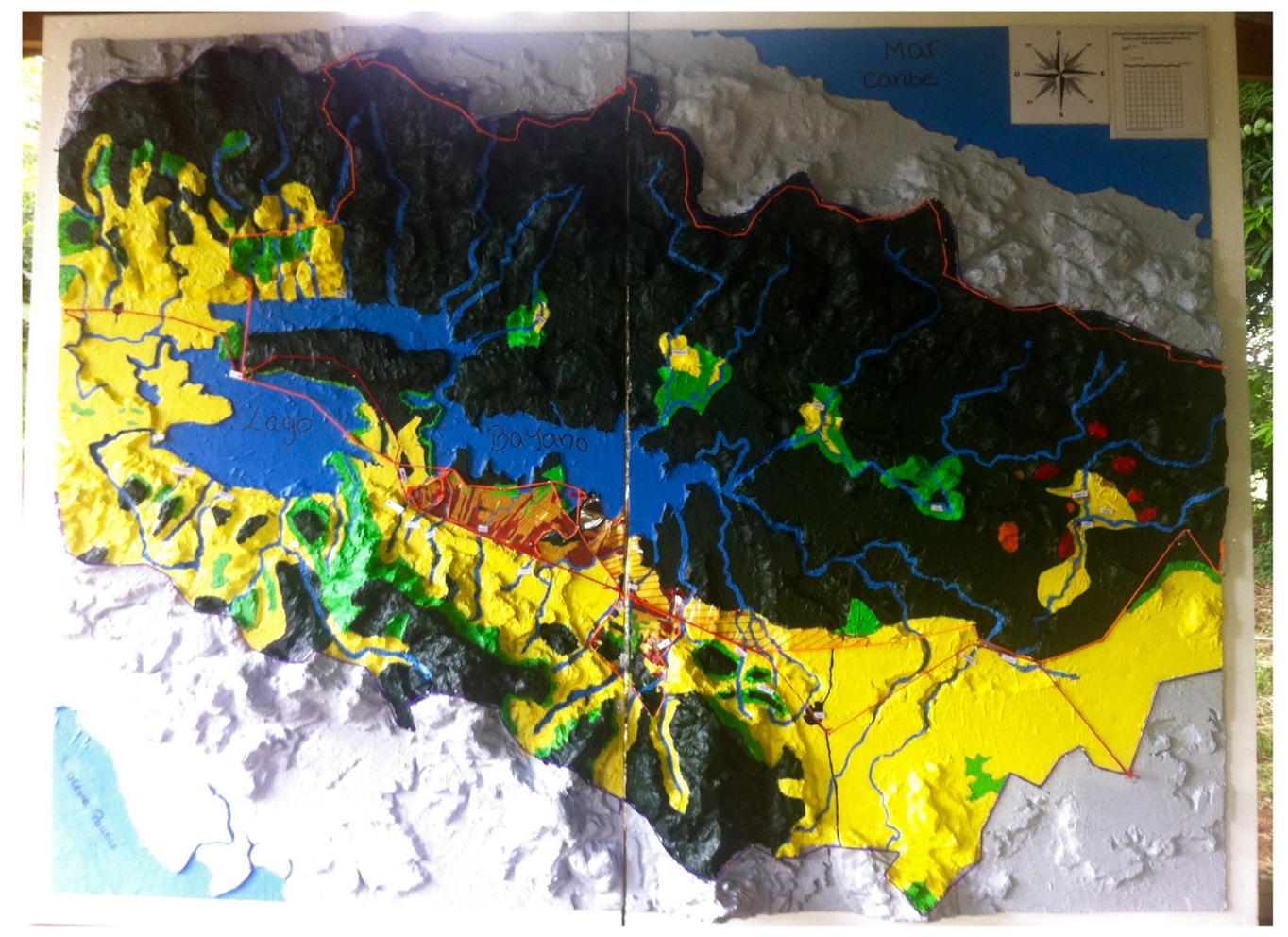

Fig. 3. The 3D model of the Upper Bayano region in August 2015.

campesinos. We acknowledge that the campesinos were unlikely to add conflicts, as it might weaken their or a friend's claim to land possession, but hypothesize that they may have wanted to remove some proposed conflict areas. Therefore, it should be noted that the two campesinos who participated only verified and confirmed conflicts listed by both indigenous sectors and did not add or subtract any. The campesinos, the last sector to participate in the conflict phase, also had to verify the information added by the Gunas. As the Gunas added no conflicts involving the Emberas, the Emberas were not asked to review the information of the Gunas. Likewise, as no conflicts were added by the campesinos, the Emberas and Gunas were not asked to review the information.

During the verification exercises, participants discussed the history of land cover and land-use conflicts involving their sector as well as present conflicts. The name under which the conflict is known in the region, the nature of the conflict (invasion or legal delimitation), the year the conflict started, the sectors involved in the conflict, and whether it is solved or not were all noted. Participants located conflicts on the model with a red pin for unsolved conflicts and a blue pin for those solved. All pins were numbered according to the numbering of the legend printed and attached to the 3D model. When a conflict involved a large area, it was indicated with a hatched red layer (Fig. 4).

\section{Results and discussion}

\section{The Bayano watershed revisited}

The P3DM exercise resulted in the creation of a common land cover representation of the Upper Bayano and conflict areas therein. The representation included land delimitation, watershed delimitation, and land cover of each sector's territory. In total, 11 conflict areas were identified by participants 


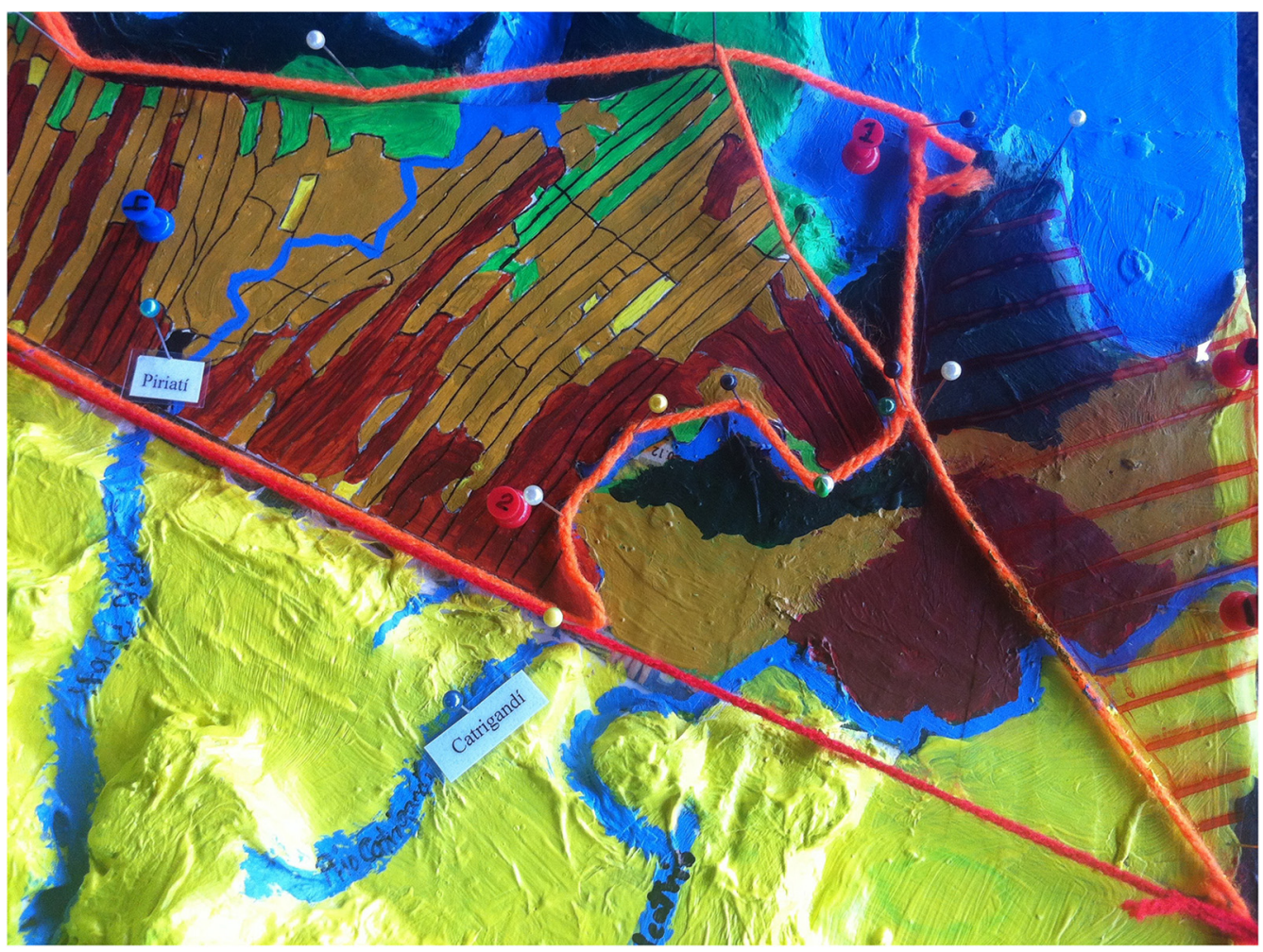

Fig. 4. Conflict representation on the model. Blue pins indicate solved conflicts, red pins indicate unsolved conflicts, and hatched red layers on the lower right corner indicate an area in conflict.

and allowed us to develop a timeline of key land cover and land-use conflicts in the region (Fig. 5). Four conflicts covered large areas of land (i.e., a territorial overlap of land delimitation between Gunas and Emberas (conflict 7; Fig. 5) and establishment of whole campesinos' communities inside indigenous land (conflicts 1, 2, and 3; Fig. 5)). Seven of the conflicts identified were assigned an exact location and consisted of invasions of particular individuals or families (conflicts 4, 5, 6, 8, 9, 10, and 11; Fig. 5). Three conflicts were identified and acknowledged as having been resolved (conflicts 4, 5, and 10; Fig. 5). In the case of conflicts 4 and 5, the Emberas won back their land in court from the campesinos who invaded Ipeti. For conflict 10, the campesinos legally received the right to stay via an official land title. Three unsolved conflicts were between Piriati's Emberas and campesinos, one conflict between Ipeti's Emberas and campesinos, one conflict between Piriati's Emberas and Gunas, and three conflicts between Gunas and campesinos. All conflicts involving campesinos were due to invasion of indigenous territories. These invasions were all located next to the Pan-American Highway (Figs. 1, 6). Participants mentioned that invasions of the Gunas' Comarca dated from resettlement in the 1970s, whereas invasions of Emberas' Collective Lands are more recent. Invasions are related to access of land for pasture or cattle ranching. Unlike the others, the conflict involving the two indigenous groups refers to an overlap in the official delimitation of the Guna's Comarca and the Collective Land of Piriati.

Once the 3D model was built, the traditional Embera authorities agreed to officially present it to Panamanian officials (i.e., the then-director of Autoridad nacional de administracion de tierras (ANATI), and the mayor of the district), television reporters from TVN channel, and local inhabitants (Arcia 2015). This presentation was held during the celebration of the Official Land Title Entry of 


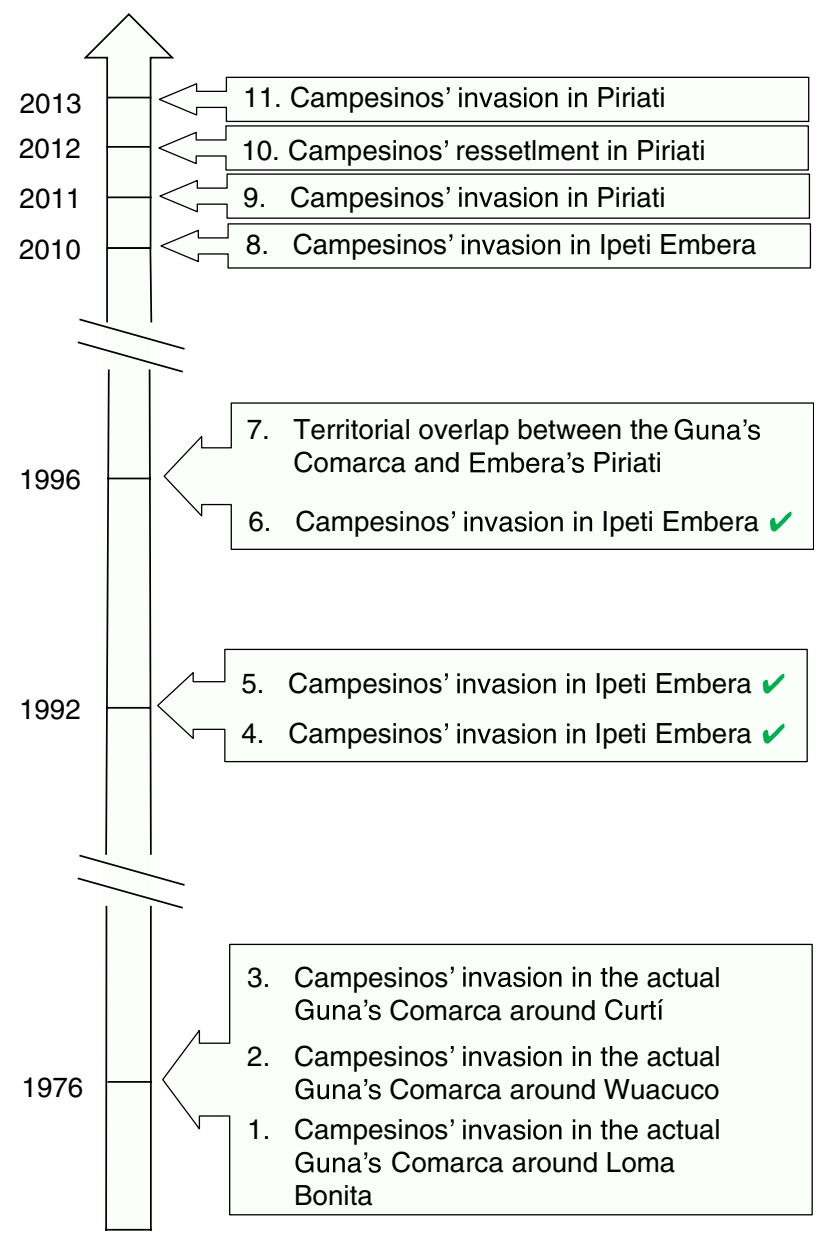

Fig. 5. Conflicts present in the Upper Bayano watershed since the resettlement in the 1970s. The Comarca Kuna de Madugandi was created in 1996, the Collective Land of Piriati obtained its land title in 2014 and that of Ipeti in 2015. Conflicts with a green check mark have now been solved.

. Territorial overlap between the Guna's

6. Campesinos' invasion in Ipeti Embera $\checkmark$

Campesinos' invasion in the actual Guna's Comarca around Wuacuco

Guna's Comarca around Loma Bonita

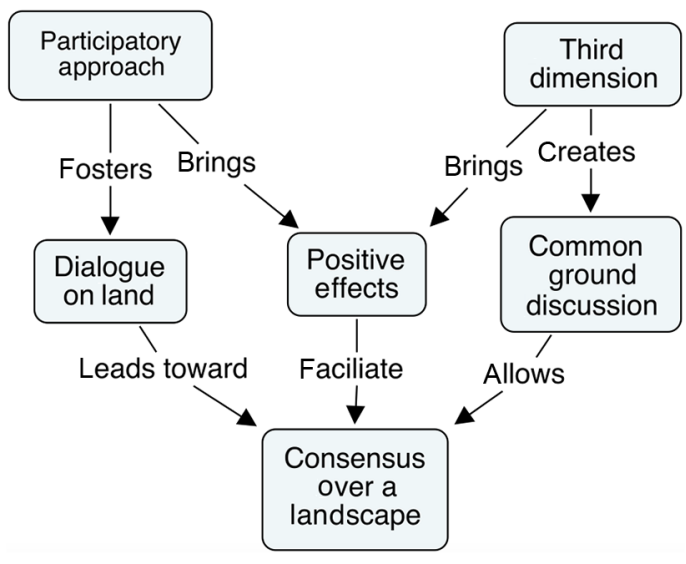

Fig. 6. Factors leading to a consensus around land and the interaction between them. Positive effects are described as the effects created by social capital (sense of equity, clarity, and trust) and by the third dimension (enthusiasm and excitement).

Ipeti Embera at the end of August 2015. Banners were displayed explaining the steps of participatory mapping and P3DM exercises as well as other activities included in the project. Several members of the Neotropical Ecology Laboratory including authors (MG, BP, and IP) were present to answer 
questions and explain the project. The presentation was a success, as was the celebration. In fact, government interest was expressed during the official presentation of the 3D model, where the then-Director of the National Land Authority (ANATI) indicated his interest in collaborating with members of Juntos para proteger nuestra Cuenca on land-use planning.

The main obstacle encountered during 3D modelling was campesinos' poor participation during the conflict discussion phase. This can be explained by two reasons. First, campesinos might not benefit from talking about and agreeing on conflicts as campesinos who invaded land might profit from an unclear land tenure regime. As a matter of fact, in previous interviews conducted by St-Laurent et al. (2013) in the region, campesinos mentioned their fear of losing land during formal projects such as REDD+. Results showed that $100 \%$ of households without rights of possession and $52.9 \%$ of households with possession rights were afraid. That same study also noted a lack of local organizations and lack of motivation or initiative to participate in REDD+. Compared with indigenous communities, campesinos communities rarely combine efforts and do not have strong organizations or political institutions to represent them at a regional, national, or international level.

\section{Building a common land cover representation using P3DM}

In vast landscapes inhabited by heterogeneous groups such as the Upper Bayano watershed, multiple actors are at the negotiation table when it comes time to reflect on land cover and land use. Stakeholders, or groups of stakeholders, likely differ in their concerns and preferred land-use options, which complicates the consensus-building task. Tan-Kim-Yong (1992) explained the importance of using simple methods and tools to create a common vision over land use and to facilitate consensus building.

Land-use planning processes often rely on maps (Evans et al. 2006) and the information presented on them provides a baseline to project future land-use scenarios. However, the understanding of spatial information presented on the map by stakeholders depends on their interpretation (Couclelis and Gottsegen 1997), with the same map possibly being interpreted differently by different actors. In a negotiation process, differential understanding of baseline representation can occasionally lead to confusion. Spatial information for land-use planning purposes must be clear and transparent, otherwise maps can lie and ignite conflicts (Monmonier 1996; Rambaldi et al. 2002).

In this project, the third dimension of a 3D model served as a catalyst to improve understanding of and interest in the spatial data (Fig. 6). As an example, during the painting process and official presentation of the 3D model, people of the region who came to see it systematically located the Bayano Bridge as a reference point. Once this fixed landscape element was located, inhabitants were able to "travel" their territory by following the spatial information presented on the model. The information of the 3D model was easily interpreted by all. These findings support previous research in which the third dimension was identified to give important cues to stimulate memory and establish spatial associations (Rambaldi et al. 2002; Rambaldi and Lanh 2003). Other studies also found that the information in a 3D model was easily understandable by all (Mascarenhas and Kumar 1991; Tan-Kim-Yong 1992; Corbett 2009, 16). We therefore argue that the third dimension allowed a common understanding of the spatial data and helped create a common baseline land cover representation (Fig. 6).

Compared with participatory mapping, the P3DM caught people's attention and excitement, making people talk about this project. For example, young participants posted photos and updates of the project on social media. This created visibility through conversations and "likes" and fuelled participants' excitement. It was striking that participants of the three sectors that participated in the P3DM did so voluntarily (i.e., without receiving salaries), which contrasts with standard practice in the region of receiving a compensatory salary for days spent working on a project. The Guna participants, when they worked on the traditional 2D mapping of their territories (Fig. 2), for example, 
were paid over the $2 \mathrm{~d}$ of the exercise, but, when it came to the 3D modelling sessions, they accepted to work as volunteers. The 3D model was something new to most people and clearly captured people's interest. Compared with a two-dimensional map, its size and vertical dimension make it an innovative and intriguing object. Similar enthusiasm has been observed in previous studies where the use of a P3DM as a concrete tool increased people's participation (Rambaldi and Lanh 2003; Maceda et al. 2009). Our experience with P3DM is therefore in line with past experience, such as that of Rambaldi et al. (2002) who used it to improve the indigenous negotiating position over a land resources dilemma with Vietnamese national park authorities. Likewise, De Vera (2005) presented the influence of a P3DM in the empowerment of indigenous peoples to advocate their demands and development priorities to the Philippine government.

From the beginning of the project, the interactive participation of all stakeholders created a sense of equity, trust, and group solidarity. We propose that it created what Berkes (2009) calls social capital among the stakeholders. At first, participants appeared shy, and participants from the three sectors did not mingle. But as the process went on, individuals of different sectors started to mix together and to work as a group. Rambaldi and Lanh (2003) mentioned that human interaction dynamics in P3DM are stepping stones towards improving stakeholders' mutual trust and the understanding of other stakeholders' positions. We consider that this increased understanding of each other's positions is especially important in a conflict area. This common definition of the problem prior to formal meetings and negotiation (Amado et al. 2014) was well illustrated when mapping land delimitation of the Comarca Kuna de Madugandi. When considering the overlap between the Comarca and the Collective Land of Piriati, a discussion arose between participants, which was brought to the attention of the Guna authorities. The authorities confirmed the existence of the conflict between both sectors (Fig. 5), with the Emberas claiming that the area was part of their ancestral land although the Gunas were given the area in 1996 when the Comarca was created. The discussion evidenced the confusion because Piriati was also officially given the area in 2014 under Law 72 of 2008 (Panama 2008; Vergara-Asenjo and Potvin 2014). Authorities of both sectors are now considering ways to resolve the situation.

Social learning, as observed in this project, is a key element in co-management systems and a central process in decision-making and environmental management (Berkes 2009). It entails collective action, evaluation, and participation to improve human and environmental interrelation management (Keen et al. 2005, 4). We argue that the social capital created by interactive participation as well as the excitement and enthusiasm created by the third dimension led to "positive effects" (Fig. 6), creating an environment favorable to discussions and harmonious relations among stakeholders. The consensus among stakeholders was not only obtained by discussing and locating conflicts with the authorities but also facilitated by the positive effects (Fig. 6). Innes and Booher (1999) found that the consensusbuilding process is not only implemented to produce agreements and plans, it is mainly about experimentation, learning, changes, and building together a shared meaning. In fact, following the P3DM, a land-use planning project based on the aspirations, needs, and world views of the different actors that inhabit the region, was initiated to elucidate a variety of land-use scenarios for the Upper Bayano watershed and to model how this area could potentially change over the following two to three decades. Upon assessing the different possible scenarios in terms of land-use change of the Upper Bayano, this project aims to facilitate the selection among all actors of an optimal land-use trajectory that supports local livelihoods, curbs territorial conflicts, and ensures the protection and restoration of forests.

\section{Conclusion}

Forest management, protection, and sustainable development are unlikely to be achieved without stable security of territory (Davis and Wali 1994) and the presence of an insightful government that can steer interest towards forest conservation (Davis and Wali 1994; Karsenty and Ongolo 2012). Official 
land title possession increases indigenous control over their land and should stimulate their active participation in forest conservation (Vergara-Asenjo and Potvin 2014). Vergara-Asenjo and Potvin (2014) showed that in Panama, indigenous territories and protected areas incurred less deforestation than other private or public land. This occurs in part because deforestation by campesinos to create de facto land title cannot happen when forested areas have secured land titles (Karsenty and Ongolo 2012). In the recent past, the Bayano watershed has undergone historical changes now making it a strong candidate for REDD+. The decision of the Inter-American Court of Human Rights in favor of Guna and Embera peoples indeed resolved most land claims (la Corte Interamericana 2014) and the work done by the project Juntos para Protejer nuestra Cuenca contributed to lessen intercultural tensions (Rodriguez 2014a).

However, forest clearing by campesinos to establish pasture is unlikely to stop easily. St-Laurent et al. (2013) reported that interviews with campesinos of the region showed that all respondents saw deforestation as more viable than forest conservation. A main challenge that faces REDD+ is therefore the development of appropriate incentives (e.g., financial support, legislation, technical assistance, and accessible credits) to stimulate active forest protection or reforestation efforts from campesinos (Sloan 2008; St-Laurent et al. 2013). Activities such as climate-smart agriculture (FAO 2011) or agroforestry (Montagnini and Nair 2004) would need to target small- and medium-sized farm holders (Sloan 2008). Because indigenous people do not engage in cattle ranching as much as campesinos (Tschakert et al. 2007), incentives would also have to be developed for sustainable forest management and conservation (FAO 2012).

\section{Acknowledgements}

We thank Lady Mancilla, Fikret Berkes, José Monteza, Jorge Ventocilla, and Javier Mateo-Vegas for their help and recommendations. We also thank the National Science and Engineering Research Council of Canada and the Margaret A. Cargill Foundation for funding this project.

\section{Author contributions}

Conceived and designed the study: MG, CP, LM, BP, DC, IP. Performed the experiments/collected the data: MG, LM, BP, DC, IP. Analyzed and interpreted the data: MG, CP. Contributed resources: MG, CP, LM, BP, DC, IP. Drafted or revised the manuscript: MG, CP, LM, BP, DC, IP.

\section{Competing interests}

The authors have declared that no competing interests exist.

\section{Data accessibility statement}

All relevant data are within the paper.

\section{References}

Amado A, St-Laurent GP, Potvin C, and Llapur R. 2014. Modelo para su resolución en preparación para la protección de bisques. In Experiencias Latinoamericanas en el Abordaje de Conflictos. Edited by A Pfund. University for Peace, San Jose, Costa Rica. pp. 81-97.

Angelsen A, Brockhaus M, and Kanninen M. 2009. Realising REDD+: national strategy and policy options. Centre for International Forestry Research, Bogor, Indonesia. 362 p. 
Arcia J. 2015. Emberás reciben su título de tierra colectiva, Las Estrella [online]: Available from http:// laestrella.com.pa/panama/nacional/emberas-reciben-titulo-tierra-colectiva/23888456.

Arthur J, Carlson C, and Moore L. 1999. A practical guide to consensus: policy consensus initiative (abbreviated version). The Policy Consensus Initiative, $11 \mathrm{p}$.

Autoridad Nacional del Ambiente. 2014. GEO Panama 2014: Informe del Estado deel Ambiente, Panama, Panama [online]. 167 p. Available from http://www.pnuma.org/deat1/pdf/GEO_Panama_2014.pdf.

Berger E. 2013. Panama indigenous groups say land under threat. Thomson Reuters Foundation News, 07/31 [online]. Available from http://www.trust.org/item/20130731093650-v4tb5/? source=hpeditorial\&siteVersion $=$ mobile.

Berkes F. 2009. Evolution of co-management: role of knowledge generation, bridging organizations and social learning. Journal of Environmental Management, 90(5): 1692-1702. doi:10.1016/j. jenvman.2008.12.001.

Corbett J. 2009. Good practices in participatory mapping: a review prepared for the international fund for agricultural development. The International Fund for Agricultural Development (IFAD), Rome, Italy. 55 p.

Couclelis H, and Gottsegen J. 1997. What maps mean to people: denotation, connotation, and geographic visualization in land-use debates. In Spatial information theory A theoretical basis for GIS. Edited by S Hirtle and A Frank. Springer, Berlin, Germany. pp. 151-162.

Davis SH, and Wali A. 1994. Indigenous land tenure and tropical forest management in Latin America. Ambio, 23(8): 485-490.

De Vera D. 2005. Mapping with communities in the Philippines: rolling with the punches. Series mapping with communities in the Philippines: rolling with the punches. In Mapping for change conference, Nairobi, Kenya, 7-10 September 2005. 6 p.

ETESA. 2013. Plan de Expansión del Sistema Interconactado Nacional 2013-2027, Panama, Panama [online]. 59 p. Available from https://www.etesa.com.pa/documentos/Plan_Expansion_2013-2027/ Tomo_II_Plan_Indicativo_de_Generacion_2013-2027.pdf.

Evans K, Bennett EM, and Zurek MB. 2006. Field guide to the future: four ways for communities to think ahead. Edited by E Bennett and $\mathrm{M}$ Zurek. Center for International Forestry Research (CIFOR), ASB, World Agroforestry Centre, Nairobi, Kenya. 87 p.

FAO. 1990. The community's toolbox: the idea, methods and tools for participatory assessment, monitoring and evaluation in community forestry [online]. Available from http://www.fao.org/docrep/ x5307e/x5307e00.htm.

FAO. 2011. Building bridges between REDD+ and sustainable agriculture: addressing agriculture's role as a driver of deforestation [online]. $4 \mathrm{p}$. Available from http://www.fao.org/climatechange/ 29723-0c174581f92a9d71a125c30981e7b42fb.pdf.

FAO. 2012. Tenure of indigenous peoples territories and REDD+ as a forestry management incentive: the case of Mesoamerican Countries [online]. UN-REDD Programme Secretariat, Geneva, Switzerland. 57 p. Available from http://www.fao.org/3/a-i2875e.pdf. 
Foody GM, Palubinskas G, Lucas RM, Curran PJ, and Honzak M. 1996. Identifying terrestrial carbon sinks: classification of successional stages in regenerating tropical forest from Landsat TM data. Remote Sensing of Environment, 55(3): 205-216. doi:10.1016/S0034-4257(95)00196-4.

Forest Carbon Partnership Facility. 2015. REDD+ countries [online]. Available from http://www. forestcarbonpartnership.org/redd-countries-1.

Gaillard J-C, and Maceda EA. 2009. Participatory three-dimensional mapping for disaster risk reduction, participatory learning and action: community-based adaptation to climate change. Participatory Learning and Action, 60: 109-118. Available from http://pubs.iied.org/pdfs/G02818.pdf.

Galudra G, Van Noordwijk M, Suyanto S, Sardi I, Pradhan U, and Catacutan D. 2011. Hot spots of confusion: contested policies and competing carbon claims in the peatlands of Central Kalimantan, Indonesia. International Forestry Review, 13(4): 431-441. doi:10.1505/146554811798811380.

Holmes I, and Potvin C. 2014. Avoiding re-inventing the wheel in a people-centered approach to REDD+. Conservation Biology, 28(5): 1380-1393. doi:10.1111/cobi.12301.

Houghton RA, House J, Pongratz J, Van der Werf G, DeFries R, Hansen M, et al. 2012. Carbon emissions from land use and land-cover change. Biogeosciences, 9(12): 5125-5142. doi:10.5194/bg-9-5125-2012.

Innes JE, and Booher DE. 1999. Consensus building and complex adaptive systems: a framework for evaluating collaborative planning. Journal of the American Planning Association, 65(4): 412-423. doi: $10.1080 / 01944369908976071$.

Karsenty A, and Ongolo S. 2012. Can "fragile states" decide to reduce their deforestation? The inappropriate use of the theory of incentives with respect to the REDD mechanism. Forest Policy and Economics, 18: 38-45. doi:10.1016/j.forpol.2011.05.006.

Keen M, Brown VA, and Dyball R. 2005. Social learning: a new approach to environmental management. In Social learning in environmental management: towards a sustainable future. Edited by M Keen, VA Brown, and R Dyball. Earthscan Publications Ltd., London, UK. pp. 3-21.

la Corte Interamericana. 2014. Caso de Los Pueblos Idígenas Kuna de Madungandí y Emberá de Bayano y sus Miembros Vs. Panamá, San José, Costa Rica [online]. 24 p. Available from http:// www.corteidh.or.cr/docs/casos/articulos/seriec_284_esp.pdf.

Le Quéré C, Moriarty R, Andrew RM, Peters G, Ciais P, Friedlingstein P, et al. 2015. Global carbon budget 2014. Earth System Science Data, 7: 47-85. doi:10.5194/essd-7-47-2015.

Maceda E, Gaillard J-C, Stasiak E, Le Masson V, and Le Berre I. 2009. Experimental use of participatory 3-dimensional models in island community-based disaster risk management. Shima, 3(1): 72-84.

Mascarenhas J, and Kumar PP. 1991. Participatory mapping and modelling users' notes. RRA Notes, 12: 9-20.

Mialhe F, Gunnell Y, Ignacio JAF, Delbart N, Ogania JL, and Henry S. 2015. Monitoring land-use change by combining participatory land-use maps with standard remote sensing techniques: showcase from a remote forest catchment on Mindanao, Philippines. International Journal of Applied Earth Observation and Geoinformation, 36: 69-82. doi:10.1016/j.jag.2014.11.007.

Monmonier M. 1996. How to lie with maps. 2nd edition. University of Chicago Press, Chicago, Illinois. 209 p. 
Montagnini F, and Nair P. 2004. Carbon sequestration: an underexploited environmental benefit of agroforestry systems. Agroforestry systems, 61: 281-295. doi:10.1023/B:AGFO.0000029005. 92691.79 .

NOOA. 2009. Stakeholder engagement strategies for participatory mapping. NOOA Coastal Services, Charleston, South Carolina, USA. 21 p.

P3DM. 2016. P3DM where? Locations of known P3DM exercises worldwide [online]. Available from http://www.p3dm.org/live-map/.

Panama. 1996. Por la cual se crea la Comarca Kuna de Madugandi. Panama, Panama [online]. pp. 53-61. Available from http://www.organojudicial.gob.pa/cendoj/wp-content/blogs.dir/cendoj/ PUEBLOS_INDIGENAS/ley_24_1996_kuna_madugandi.pdf.

Panama. 2008. Ley 72: Que establece el procedimiento especial para la adjudicacion de la propriedad colectiva de tierra de los pueblos indigenas que no estan dentro de las comarcas. Panama, Panama [online]. 4 p. Available from http://www.anati.gob.pa/Normativa/Ley_72_ de_2008_Propiedad_Colectiva_de_Tierras_Indigenas.pdf.

Potvin C, Mateo-Vega J, Spencer K, and Belliard S. In Preparation. Elucidating land-use dynamics and decision-making pathways among colonist farmers in eastern Panama.

Rambaldi G. 2010. Participatory three-dimensional modelling: guiding principles and applications. 2010 edition. CTA, Wageningen, the Netherlands. 86 p.

Rambaldi G, and Lanh VA. 2003. The seventh helper: the vertical dimension feedback from a training exercise in Vietnam. Participatory Learning and Action Notes, 46: 77-83.

Rambaldi G, Bugna S, Tiangco A, and de Vera D. 2002. Bringing the vertical dimension to the negotiating table: preliminary assessment of a conflict resolution case in the Philippines. ASEAN Biodiversity, 2(1): 17-26.

Rambaldi G, Muchemi J, Crawhall N, and Monaci L. 2007. Through the eyes of hunter-gatherers: participatory 3D modelling among Ogiek indigenous peoples in Kenya. Information Development, 23(2-3): 113-128. doi:10.1177/0266666907078592.

Rodriguez L. 2014a. Realizan encuentro entre campesinos e indígenas en Bayano, LaPrensa [online]. Available from http://www.prensa.com/luis_rodriguez/Realizan-encuentro-campesinos-indigenasBayano_0_4064593635.html.

Rodriguez LA. 2014b. Vuelve la tensión a región de Alto Bayano, LaPrensa, 11/15 [online]. Available from http://impresa.prensa.com/nacionales/Vuelve-tension-region-Alto-Bayano_0_4073592667. html.

Sloan S. 2008. Reforestation amidst deforestation: simultaneity and succession. Global Environmental Change, 18(3): 425-441. doi:10.1016/j.gloenvcha.2008.04.009.

Srimongkontip S. 2000. Building the capacity of watershed networks to resolve natural resource conflicts: field experiences from the Care-Thailand Project. Asian Pacific Communication for Newsletter, 13(2): 46-50.

St-Laurent GP, Gélinas N, and Potvin C. 2013. REDD+ and the agriculture frontier: understanding colonists' utilization of the land. Land Use Policy, 31: 516-525. doi:10.1016/j.landusepol.2012.08.017. 
Sunderline WD, Larson AM, and Cronkleton P. 2009. Forest tenure rights and REDD+: from inertia to policy solutions. In Realizing REDD+: National Strategy and Policy Options. Edited by A Angerlsen. Centre for International Forestry Research, Bogor, Indonesia. pp. 139-149.

Tan-Kim-Yong U. 1992. Participatory land-use planning for natural resource management in northern Thailand. Rural Development Forestry Network Paper, 14(b): 1-25.

Tschakert P, Coomes OT, and Potvin C. 2007. Indigenous livelihoods, slash-and-burn agriculture, and carbon stocks in eastern Panama. Ecological Economics, 60(4): 807-820. doi:10.1016/j. ecolecon.2006.02.001.

United Nations. 2015. Adoption of the Paris Agreement. Series adoption of the Paris Agreement. In Conference of the Parties. Paris, France, 31 p.

Vergara-Asenjo G, and Potvin C. 2014. Forest protection and tenure status: the key role of indigenous peoples and protected areas in Panama. Global Environmental Change, 28: 205-215. doi:10.1016/j. gloenvcha.2014.07.002.

Vergara-Asenjo G, Mateo-Vega J, and Potvin C. Submitted. A participatory approach to elucidate the consequences of land invasion on forests and REDD+ initiatives. PLoS ONE.

Vergara-Asenjo G, Sharma D, and Potvin C. 2015. Engaging stakeholders: assessing accuracy of participatory mapping of land cover in Panama. Conservation Letters, 8(6): 432-439. doi:10.1111/ conl.12161.

Wali A. 1989. Kilowatts and crisis: hydroelectric power and social dislocation in eastern Panama. Westview Press, Boulder, Colorado, USA. 205 p. 